\title{
The Influence of Corporate Reputation on Affective Organizational Commitment: The Role of Value Congruence as Mediator
}

\author{
Vildan Esenyel \\ Faculty of Business \& Economics, Girne American University, Kyrenia- North Cyprus
}

\begin{tabular}{l}
\hline \\
Keywords: \\
Perceived Corporate, Affective \\
Organizational Commitment, \\
Value Congruence, North \\
Cyprus \\
Received \\
07 January 2020 \\
Received in revised form \\
05 March 2020 \\
Accepted \\
13 April 2020 \\
\hline
\end{tabular}

\begin{abstract}
This study focuses on the relationship between perceived corporate reputation and employees' affective organizational commitment with the mediating role of value congruence between the employee and the organization. A quantitative questionnaire-based survey is used to test the research model with a descriptive approach. The data were collected from employees across multiple private small and medium-sized enterprises and sectors operating in North Cyprus. In order to test the conceptual framework, partial least square (PLS) was used. Some empirical indicators are conducted by using PLS-SEM to examine the reliability and validity of the study. The results revealed that value congruence partially mediates the relationship between perceived corporate reputation and affective organizational commitment. Furthermore, the results showed that perceived positive corporate reputation has a positive impact on affective organizational commitment. This study fills the gap by analyzing the impact of corporate reputation on affective commitment from the employees' perspective. The results led to theoretical and managerial implications related to strategic management.
\end{abstract}

Correspondence:

vildanesenyel@gau.edu.tr

CCIKD Publishing

Gotsi and Wilson (2001) stated that behaviors of the employees characterize institution in the eyes of the external audiences, and they stated that they reflect the image of the institution and the reputation of the institution in the sum of these images. Also, since Gotsi and Wilson understood the importance of the employees of today's institutions in terms of corporate reputation management, they stated that they included employees in corporate communication activities in order to convey the same message to all stakeholders. Fombrun (1995) stated that corporate 
reputation is vital for employees, and the employees serve the corporate reputation as the perfect source and that they provide competitive advantages in sharing company's reputation with the potential customers, existing customers, and all other social stakeholders.

An employee, who has an emotional connection with his/her institution, will be able to identify himself/herself with the institution as a result will become a reliable and loyal individual and will affect the corporate reputation positively (Cravens, \& Oliver, 2006). One of the most relevant aspects of influencing target audience is convincing employees. Employees are at the top of a communication campaign. Employees emit the message of their business and add strength (Collins, $\&$ Han, 2004). If the employees do not adopt the communication method of the enterprise, the adoption of the target audience becomes doubtful (Van Hoye \& Lievens, 2009). The prominent aim of this research is to reveal if the perceptions of corporate reputation affect employees' affective organizational commitment. In the global economy, the reputation of organization in both production and service enterprises is an essential competitive tool (Carmeli \& Cohen, 2001). In order to reach a particular position for stakeholders, it is known that this competitive tool should be professionally managed, especially for employees to create an organizational commitment, to increase loyalty and efficiency (Carmeli, Gilat, \& Weisberg, 2006). To be well known in today's business world, in other words, to be the right institution in terms of maintaining a corporate reputation is also essential.

The scarcity of skilled employees has become an increasingly severe problem all over the world, and small businesses report it as one of the most critical obstacles to find qualified staff (LopezPerez, Melero, \& Javier Sese, 2017). The major aim of this study is to investigate how perceived reputation affects employees' affective organizational commitment and whether the reputation management is an essential priority in management and human resources. Additionally, this study examines the mediation effect of value congruence on the relationships between employees' perceived reputation and their organizational commitment in the private firms of North Cyprus.

\section{Theoretical Background and Hypothesis Development}

\section{Perceived Corporate Reputation}

As stated by Men (2014), the importance of employees as communication assets should not be ignored, especially in today's new media environments. Employees are a critical audience in the management of corporate reputation (Gotsi \& Wilson, 2001) because it is the duty of every employee to maintain and improve the reputation of the organization (Saxton, 1998). Now, through social media, employees have the opportunity to communicate with others and initiate 
public dialogues. How employees perceive the organization determines what they say in public, and their views are the basis of how other stakeholders perceive organizational credibility (Fombrun, Van Riel, \& Van Riel, 2004). Besides, employees' family and friends can serve as a third party for organizations. Therefore, the contribution that employees can make to increase company's reputation is significant and often free. Furthermore, having a good reputation in the eyes of employees strengthens employee identity with the company's mission, vision, values, beliefs, and goals, and enhances employee loyalty, motivation, and commitment, resulting in higher business performance and contributing to organizational effectiveness (Esenyel \& Emeagwali, 2019). The individual believes and feels that taking part in a reputable organization will give him / her respect in society. The trust of the society towards the institution of the individual resolves concerns regarding the future of the individual and therefore makes the individual feel safe. Employees who trust in the business and who feel that the future is guaranteed, morale and motivation are rising, adherence to the institution is increasing (Cravens, \& Oliver, 2006). In particular, the loyalty of employees with the loyal customer profile is increasing. Such situations enable the organization to get the full support of the employees even during the crisis and strengthen the team spirit.

\section{Value Congruence}

The significance of having organizational members whose psychological attachment is based on more than simple compliance has recently been highlighted by Smith, Organ, and Near (1983) in a study of organizational citizenship behavior. They note that many critical behaviors in organizations rely on acts of cooperation, altruism, and spontaneous unrewarded help from employees. Katz (1964) also observed that one class of essential behaviors for a functioning organization consisted of those innovative behaviors that go beyond role prescriptions. According to Mowday, Steers, and Porter (1979), there are many situations in which organizations need individual members, especially those in critical positions, to move above and beyond the call for duty for the benefit of organizations. In the motivation base for such extra actions is likely to require more than just simple compatibility, and the failure to develop this psychological link between the members may require the organization to incur increased costs associated with more comprehensive and sophisticated control systems.

The fundamental values, beliefs, and norms adopted by employees are the most fundamental characteristics that distinguish successful organizations from others (Cable \& Judge, 1994). The influential culture within organization, which arises from the existence of individual-organizational harmony, ensures the harmony of the individual with the organization and the environment by a common purpose (Siltaoja, 2006). The influential culture, which is formed, constitutes a great workforce with organizational commitment, 
particularly affective commitment. Increasing these characteristics within the organization brings about an increase in organizational citizenship behavior (Hong \& Yang, 2009).

\section{Affective Organizational Commitment}

Organizational commitment is a subject that is widely debated in the field of organizational behavior in terms of the possible consequences and implications for enterprises. Some of the results that make organizational commitment valuable are that individuals are determinant in their intention to quit and that employees with high organizational commitment have higher performance and higher organizational effectiveness (Steers, 1977). The researches show that employees with high organizational commitment are more involved in carrying out their duties; they stay longer in the organization and have positive relations with the organization (Huber, Northcraft, \& Neale, 1990).

Becker (1992) defined organizational commitment as the psychological attachment of employees to the workplace. Organizational commitment, which is a combination of loyalty and organizational concepts, is the desire of employee to believe in the goals and values of organization, to make efforts to realize the aims of the organization, to remain as a member of the organization (Roberts \& Dowling, 1997). Therefore, based on prior arguments, the following hypotheses are proposed:

H1. There is a positive relationship between perceived corporate reputation and value congruence

H2. There is a positive relationship between value congruence and affective organizational commitment

H3. There is a positive relationship between perceived corporate reputation and affective organizational commitment

H4. The positive relationship between perceived corporate reputation and affective organizational commitment is mediated by value congruence.

Figure 1 presents Conceptual research model. 


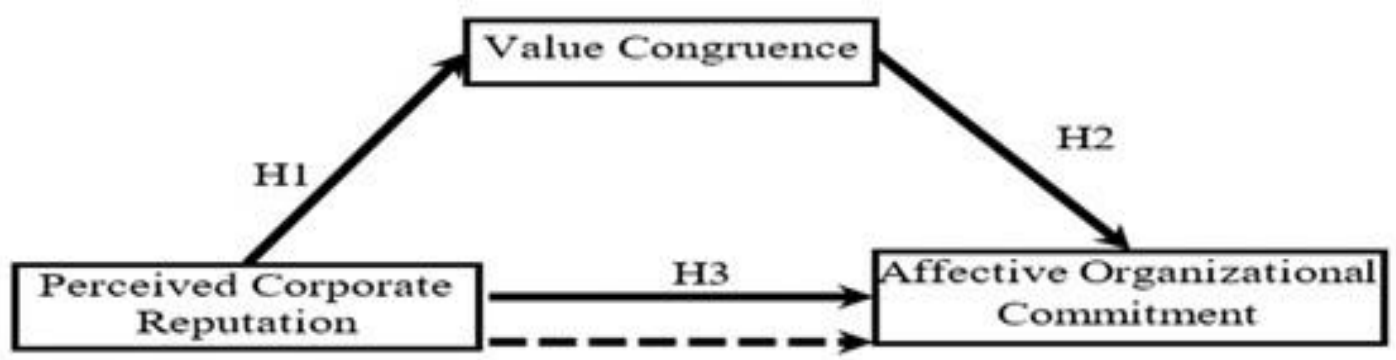

H4

Figure 1. Conceptual research model

\section{Method}

\section{Participants and Procedures}

Descriptive statistics give an understanding of the demographic profiles of the respondents. Based on the analysis, the response rate was $75 \%$. Within these respondents, $49.3 \%$ were males, and $50.7 \%$ were females. Out of 562 respondents, the age group of 22-37 years were most represented (47.5\%), followed by $38-53$ years $(38.8 \%)$, 54-72 years $(9.3 \%)$, and 18 21 years $(4.4 . \%)$. The majority of the respondents $(59.6 \%)$ had an undergraduate degree, 11.4. \% had an associate degree, $9.8 \%$ had a master's degree, and $16.2 \%$ had a high school education. Respondent's distribution by job role shows that employees had the highest representation $(44.8 \%)$, and the top management $(15.8 \%)$ and specialist $(0.5 \%)$ had the least representation. Almost, $40.6 \%$ of the respondents had experienced between one to five years and $29.5 \%$ with 6-10 years in their current workplace. This shows that mostly the employees had enough experience with the company to evaluate its reputation.

For this study, the sample was selected using a stratified random sampling technique. Measurement problems are identified and introduced by PLS-SEM data analysis technique. A Partial Least Square (PLS-SEM) approach using SmartPLS 3.0 software was found to be a suitable approach because it allows both reflective and formative structures to be studied together.

\section{Instruments}

In order to measure the dimensions of the corporate reputation, the 20 -items scale of Fombrun, Gardberg, and Sever (2000) was used. The perceived corporate reputation was accepted as a second-order multidimensional structure and defined as a variable with formative indicators (Bollen, \& Lennox, 1991). Therefore, the observed variables used to measure the perceived corporate reputation represent the reasons why a company has a particular reputation (Helm \& Klode, 2011). In order to measure the construct of organizational commitment, the scale of Meyer and Allen (1997) was adopted. Considering 
affective organizational commitment a unidimensional construct, the affective commitment was measured through these particular scales. In order to measure perceived congruence between the organization's and the employee's values, the three-item personorganization fit scale by Cable and DeRue (2002) was retained. Responses were given on a five-point Likert-type scale in which (1) corresponds to "Completely Disagree" and (5) "Completely agree."

\section{Results}

\section{Validity Test}

The statistical software IBM SPSS 23 has been employed to perform the statistical analyses. Some empirical indicators were conducted by using PLS-SEM to examine the reliability and validity of this study. As shown in Table 1, all the factor loadings were greater than 0.7 , and Cronbach's $\alpha$ was greater than 0.8 . Also, the values of composite reliability were greater than 0.9 and the values of the average variance extracted were greater than 0.5 , which suggests that this study holds acceptable reliability and validity (Fornell \& Larcker, 981). The values of factor loadings, composite reliability, Cronbach's $\alpha$ and average variance extracted are shown in Table 1 and Table 2.

Table 1

Measurement Model Estimation

\begin{tabular}{|c|c|c|c|c|}
\hline Item No. & Weights & $\mathrm{t}$-value & Loadings & $\alpha$ \\
\hline \multicolumn{5}{|l|}{ REP } \\
\hline REPEA1 & .04 & 2.74 & & \\
\hline REPEA2 & .30 & 3.49 & & \\
\hline REPEA3 & .69 & 3.60 & & \\
\hline REPPS1 & .38 & 4.95 & & \\
\hline REPPS2 & .11 & 1.83 & & \\
\hline REPPS3 & .48 & 7.47 & & \\
\hline REPPS4 & .07 & 3.90 & & \\
\hline REPVL1 & .46 & 8.30 & & \\
\hline REPVL2 & .16 & 3.66 & & \\
\hline REPVL3 & .44 & 5.81 & & \\
\hline REPWE1 & .47 & 7.28 & & \\
\hline REPWE2 & .58 & 7.03 & & \\
\hline REPWE3 & .04 & 1.45 & & \\
\hline REPSE1 & .21 & 4.36 & & \\
\hline REPSE2 & .46 & 5.19 & & \\
\hline REPSE3 & .44 & 3.66 & & \\
\hline REPFP1 & .24 & 4.23 & & \\
\hline REPFP2 & .12 & 2.66 & & \\
\hline REPFP3 & .46 & 4.70 & & \\
\hline REPFP4 & .47 & 7.12 & & \\
\hline OCA & & & & .93 \\
\hline OCA1 & & 48.97 & .94 & \\
\hline OCA2 & & 30.30 & .84 & \\
\hline OCA3 & & 27.69 & .80 & \\
\hline OCA5 & & 26.70 & .79 & \\
\hline OCA6 & & 29.52 & .72 & \\
\hline OCA7 & & 23.97 & .72 & \\
\hline OCA8 & & 23.64 & .94 & \\
\hline VALUE & & & & .97 \\
\hline VC1 & & 127.53 & .93 & \\
\hline $\mathrm{VC} 2$ & & 120.11 & .96 & \\
\hline VC3 & & 118.29 & .96 & \\
\hline
\end{tabular}


Table 2

Discriminant Validity Reports

\begin{tabular}{llllll}
\hline & CR & AVR & OCA & PCR & VC \\
\hline OCA & .92 & .65 &. $\mathbf{7 4}$ & & \\
PCR & .96 & .54 & .80 & .75 & .70 \\
VC & .97 & .91 & .80 & .95 \\
\hline
\end{tabular}

\section{Hypothesis Testing}

The results indicated that the perceived corporate reputation has a significant positive relationship with the value congruence $(\beta=.70, p<.001)$. The effect of the value congruence on affective organizational commitment $(\beta=.58, p<.001)$, and the perceived corporate reputation on affective organizational commitment $(\beta=.32, p<.005)$ are also positive. Thus, $\mathrm{H}_{1}, \mathrm{H}_{2}$, and $\mathrm{H}_{3}$ are supported (Table 3).

Table 3

Path Analysis Results

\begin{tabular}{ccc}
\hline Hypothesis & Path & Standard Coefficient \\
\hline 1 & $\mathrm{PCR} \longrightarrow \mathrm{VC}$ & $.70^{* *}$ \\
2 & $\mathrm{VC} \longrightarrow \mathrm{OCA}$ & $.58^{* *}$ \\
3 & $\mathrm{PCR} \longrightarrow \mathrm{OCA}$ & $.32^{*}$ \\
\hline
\end{tabular}

\section{Mediation Effect}

The values attained through the path analysis for the analysis of the mediation effect demonstrate that there is a partial mediation of value congruence between perceived corporate reputation and affective organizational commitment. The significance value obtained between perceived corporate reputation and affective organizational commitment on introducing the mediator is $\beta=.38, t=10.90$. This indicates that the value congruence partially mediates the relationship between perceived corporate reputation and affective organizational commitment, thereby $\mathrm{H}_{4}$ is partially accepted (Baron \& Kenny, 1986).

\section{Discussion}

The main objective of this study was to examine the effect of perceived corporate reputation on affective commitment. The structural model of PCR predicts $76 \%$, which means that the latent variable PCR substantially explain $76 \%$ of the variance in the OCA endogenous latent variable. Carmeli and Freund (2002) also found a close relationship between corporate reputation and affective commitment. Dutton, Dukerich, and Harquail (1994) have examined the relationship between organizational identification, business performance and perceptions of organizational prestige. They mentioned that if employees think that organizations are perceived positively from the outside, they will feel a more connection with their organizations. According to Allen and Meyer (1990), affective commitment shows positive psychological commitment to a firm based on identification. These perceptions also affect employers' loyalty to their employers, as the perceptions of the employer affect the self-esteem of the employee. Therefore, working for a reputable 
company provides a stronger basis for commitment rather than working for a malicious employer [Cable, \& Turban, 2001; Fombrun, 1995; Helm, 2007).

\section{Practical Contribution}

Corporate reputation management, first of all, starts with strong relations with stakeholders. In developing good relations, it is necessary to determine the needs of different denominator groups and to consider these needs. Differences in expectations will also affect perceptions positively or negatively. The task of developing a corporate reputation is to reduce the views of different stakeholders by bringing together the priorities of different stakeholders in a common denominator. For example, consumers take into account the quality of the products and services offered, as well as the collective sensitivity of the organization, and they are interested in business ethics and social policies. While employees focus on working conditions and personnel policies, investors have different expectations for increasing shareholder value of institutions. Thus, a multi-faceted and grounded communication plan is one of the basic principles of corporate reputation.

It is crucial to determine the identity of institution and the image of corporation, how stakeholders see business and how the identity of organization has an impact on employees both in the enterprise and outside the business. The main aim of this process is to demonstrate the consistency of the actions and discourses the enterprise. If there is a mismatch between the corporate image and the actions reflected by the business, it creates a cognitive discrepancy with these stakeholders, which adversely affects the sale of the enterprise. If it is acknowledged that there is a holistic view of the corporate stakeholders' perceptions of the enterprise, it will be revealed that the current situation analysis in reputation management should start with the measurement of the perceptions of the stakeholders.

\section{Limitations}

In this study, some limitations are related to time, access and financial constraints. The sampling method and the number of samples are other limitations that need to be addressed. Although the stratified random sample is selected and the minimum sample size is exceeded, the generalization is limited to the sample of this study. Although the randomization criterion was met for the companies in North Cyprus, the randomization for the employees in the company could not be met as the questionnaires were given to managers to distribute. Due to the scope as mentioned earlier, this research lacks the contribution of interpretative, critical or other alternative approaches. Moreover, there is no opinion that the methods other than the research method applied for this study will show different findings. The findings are bounded to the research model used in this study. Apart from the variables conceptualized in the research model, there may be other untested 
variables that may improve the model. There may be some other research models that can also clarify employees' behavioral intentions. Finally, the study was conducted in the Turkish Republic of Northern Cyprus (T.R.N.C), and the sample was chosen from North Cyprus, and the results are based on the data collected. Therefore, the scope of the study is limited contextually to North Cyprus.

\section{Concluding Remarks}

The corporate reputation, which is considered to be one of the most important values that institutions have today, provides essential opportunities in terms of making them different and being superior in competition. With the technological developments and the emerging global market environments, corporations have to position themselves in the minds of their target audience in order to be successful and therefore have to create strong positions. One of the most important differentiating factors in the minds of the target masses is their strong reputation from the most critical abstract values of the institutions. In other words, the creation, protection, and management of the corporate values as a result of reputation studies, which have been shown to offer significant opportunities in terms of both financial and human resources, have become a necessity. Institutions will be able to influence the talented staff in the market with a reputation they wish to possess, to work in that institution, so that the talented staff will work in order to contribute to the institution and as a reflection of this, the customer's relations will develop, the quality of its products and services will increase, and the financial inputs will increase.

On the other hand, with a positive reputation, the target masses will have the sympathy, trust and work with the institution. In other words, both the internal target groups and the external audience will be used to create emotional links. The emotional bonds created by these will create the intellectual assets that affect the physical assets of the institutions or the values of the institutions. Qualified, highly motivated, organization-related employees directly affect organizational performance. Since the employees have direct contact with organization's customers, suppliers, and all the other stakeholders, their positive or negative attitudes directly affect the organization. Therefore, the employee shapes the stakeholder perceptions of the organization.

For this reason, organizations should try to incorporate high-quality employees, retain existing skilled employees, and increase the motivation to maximize efficiency, and therefore strive to increase organizational performance. It is inevitable that proper reputation management can be achieved by the happiness of the employees. The employee who feels happy as an individual in the institution reflects his/her identity to the external stakeholders correctly. The employee who cannot integrate with the institution cannot accurately reflect the vision, mission, and values of the organization. 


\section{References}

Allen, N. J., \& Meyer, J. P. (1990). The measurement and antecedents of affective, continuance and normative commitment to the organization. Journal Of Occupational Psychology, 63(1), 1-18.

Baron, R. M., \& Kenny, D. A. (1986). The moderator-mediator variable distinction in social psychological research: Conceptual, strategic, and statistical considerations. Journal Of Personality And Social Psychology, 51(6), 11-73.

Becker, T. E. (1992). Foci and bases of commitment: are they distinctions worth making? Academy Of Management Journal, 35(1), 232-244.

Bollen, K., \& Lennox, R. (1991). Conventional wisdom on measurement: A structural equation perspective. Psychological Bulletin, 110(2), 305-314.

Cable, D. M., \& DeRue, D. S. (2002). The convergent and discriminant validity of subjective fit perceptions. Journal Of Applied Psychology, 87(5), 875-884.

Cable, D. M., \& Judge, T. A. (1994). Pay preferences and job search decisions: A person-organization fit perspective. Personnel Psychology, 47(2), 317-348.

Cable, D. M., \& Turban, D. B. (2001). Establishing the dimensions, sources and value of job seekers' employer knowledge during recruitment. Research in Personnel and Human Resources Management, 20, 115-163.

Carmeli, A., \& Cohen, A. (2001). Organizational reputation as a source of sustainable competitive advantage and above-normal performance: an empirical test among local authorities in Israel. Public Administration \& Management: An Interactive Journal, 6(4), 122-165.

Carmeli, A., \& Freund, A. (2002). The relationship between work and workplace attitudes and perceived external prestige. Corporate Reputation Review, 5(1), 51-68.

[10] Carmeli, A., Gilat, G., \& Weisberg, J. (2006). Perceived external prestige, organizational identification and affective commitment: A stakeholder approach. Corporate Reputation Review, 9(2), 92-104.

Collins, C. J., \& Han, J. (2004). Exploring applicant pool quantity and quality: The effects of early recruitment practice strategies, corporate advertising, and firm reputation. Personnel Psychology, 57(3), 685-717.

Cravens, K. S., \& Oliver, E. G. (2006). Employees: The key link to corporate reputation management. Business Horizons, 49(4), 293-302.

Dutton, J., Dukerich, J., \& Harquail, C. V. (1994). Organizational images and membership commitment. Administrative Science Quarterly, 39(2), 239-263.

Esenyel, V., \& Emeagwali, O. (2019). The relationship between perceived corporate reputation and employee's positive word of mouth behavior: The mediation effect of trust to managers. Management Science Letters, 9(5), 673-686.

Fombrun, C. J. (1995). Reputation: Realizing value from the corporate image. Boston, MA: Harvard Business School Press.

Fombrun, C. J., Gardberg, N. A., \& Sever, J. M. (2000). The Reputation Quotient SM: A multi-stakeholder measure of corporate reputation. Journal of Brand Management, 7(4), 241-255

Fombrun, C. J., Van Riel, C. B., \& Van Riel, C. (2004). Fame and fortune: How successful companies build winning reputations. United States: FT Press.

Fornell, C., \& Larcker, D. F. (1981). Structural equation models with unobservable variables and measurement error. Algebra And Statistics, 18(3), 382-388.

Gotsi, M., \& Wilson, A. (2001). Corporate reputation management:“living the brand”. Management Decision, 39(2), 99-104.

Helm, S. (2007). One reputation or many? Comparing stakeholders' perceptions of corporate reputation. Corporate Communications: An International Journal, 12(3), 238-254.

Helm, S., \& Klode, C. (2011). Challenges in measuring corporate reputation. Reputation Management, 99-110.

Hong, S. Y., \& Yang, S. U. (2009). Effects of reputation, relational satisfaction, and customer-company identification on positive word-of-mouth intentions. Journal of Public Relations Research, 21(4), 381-403. 
Huber, V. L., Northcraft, G. B., \& Neale, M. A. (1990). Effects of decision strategy and number of openings on employment selection decisions. Organizational Behavior and Human Decision Processes, 45(2), 276-284.

Katz, D. (1964). The motivational basis of organizational behavior. Behavioral Science, 9(2), 131-146.

Lopez-Perez, M. E., Melero, I., \& Javier Sese, F. (2017). Management for sustainable development and its impact on firm value in the SME context: Does size matter? Business Strategy and the Environment, 26(7), 985-999.

Men, L. R. (2014). Internal reputation management: The impact of authentic leadership and transparent communication. Corporate Reputation Review, 17(4), 254-272.

Meyer, J. P., \& Allen, N. J. (1997). Commitment in the workplace: Theory, research, and application. Thousand Oaks, Ca: Sage.

Mowday, R. T., Steers, R. M., \& Porter, L. W. (1979). The measurement of organizational commitment. Journal Of Vocational Behavior, 14(2), 224-247.

Roberts, P. W., \& Dowling, G. R. (1997). The value of a firm's corporate reputation: How reputation helps attain and sustain superior profitability. Corporate Reputation Review, 1(1), 72-76.

Saxton, M. K. (1998). Where do reputations come from? Corporate Reputation Review, 1(4), 393-399.

Siltaoja, M. E. (2006). Value priorities as combining core factors between CSR and reputation-a qualitative study. Journal of Business Ethics, 68(1), 91-111.

Smith, C. A., Organ, D. W., \& Near, J. P. (1983). Organizational citizenship behavior: Its nature and antecedents. Journal Of Applied Psychology, 68(4), 653-663.

Steers, R. M. (1977). Antecedents and outcomes of organizational commitment. Administrative Science Quarterly, 22(1), 46-56.

Van Hoye, G., \& Lievens, F. (2009). Tapping the grapevine: A closer look at word-of-mouth as a recruitment source. Journal of Applied Psychology, 94(2), 341-352. 